\title{
MASS STRANDing OF BAIRD's BEAKED WHALES at San Jose Island, Gulf of California, Mexico
}

\author{
Jorge Urbán R. ${ }^{1, *}$, Gustavo Cárdenas-Hinojosa ${ }^{1}$, Alejandro Gómez-Gallardo U. ${ }^{1}$, \\ Úrsula GonzÁlez-Peral ${ }^{1}$, Wezddy del Toro-Orozco ${ }^{1}$ and Robert L. Brownell Jr. ${ }^{2}$
}

\begin{abstract}
Aвstract: The Baird's or giant beaked whale (Berardius bairdii) is endemic to the North Pacific Ocean. In the eastern North Pacific, seasonal movements are poorly understood. Historic California catches suggest two peaks of abundance, in July and October. Mass strandings of Baird's beaked whales are rare. Prior to this report only two records were known, in the Bay of La Paz, Mexico in 1986 and Sagami Bay, Japan, in 1987; both mass strandings included male and females. Here we report a mass stranding of 10 Baird's beaked whales at San Jose lsland in the Gulf of California on 31 July 2006. The group was composed only by males ranging from $9.97 \mathrm{~m}$ to $11.05 \mathrm{~m}$. The estimated age, based on the dental group layers, ranged from 9 to 42 years. The cause of this stranding is unknown, although with the large number of squid also found dead in the area, it is possible that the whales could have been following the squid, one of their main prey. The mass stranding of 10 mature males reported here supports the idea of a seasonal presence, during summer, of this species in the waters of the southwest Gulf of California. The group composition supports a reproductive strategy where the old males have a major role in the guidance and protection of inexperienced weaned and young males, unlike sperm whale bachelor groups, where all males are typically the same age.
\end{abstract}

Resumen: El zífido de Baird (Berardius bairdii) es endémico del Océano Pacífico Norte. En el Pacífico Nororiental sus movimientos no se conocen bien. Las capturas históricas en las costas de California sugieren dos picos de abundancia en julio y octubre. Los varamientos masivos del zífido de Baird son raros. Previos a este reporte se conocen sólo dos registros, uno en la Bahía de La Paz, México, en 1986, y otro en la Bahía de Sagami, Japón, en 1987; en ambos varamientos se encontraron machos y hembras. En este trabajo informamos sobre un varamiento masivo de 10 zífidos de Baird en la Isla San José, Golfo de California el 31 de julio de 2006. El grupo estuvo compuesto sólo por machos que midieron entre 9.97 y $11.05 \mathrm{~m}$. Su edad estimada, con base en los grupos de bandas en el cemento de sus dientes, fue de 9 a 42 años. La causa del varamiento es desconocida, sin embargo numerosos calamares gigantes se encontraron muertos en la playa del varamiento, es posible que los zífidos hayan estado siguiendo a los calamares que son una de sus presas principales. El varamiento de diez machos maduros que se informa aquí apoya la idea de la presencia estacional durante el verano de esta especie en el suroeste del Golfo de California. La composición del grupo corresponde a la propuesta de una estrategia reproductiva donde los machos viejos tienen una función importante en la protección de los machos jóvenes inexpertos, a diferencia de los cachalotes, donde los grupos de "solteros" están formados por machos de edad similar.

KeYwords: Baird's beaked whale, Berardius bairdii, mass stranding, Gulf of California

\section{Introduction}

The Baird's or giant beaked whale (Berardius bairdii) is endemic to the North Pacific Ocean and adjacent seas (Bering Sea, Okhotsk, Sea of Japan, and the Sea of Cortez in the southern Gulf of California, Mexico) (Leatherwood et al., 1988; Balcomb, 1989). Off the Pacific coast of Japan, the whales appear in May in waters over the continental slope and their numbers increase toward summer and then decrease in October (Kasuya, 2002). In the eastern North Pacific, seasonal movements are poorly understood. Historic California catches suggest two peaks of abundance, in July and October. Off British Columbia, the majority have been killed in August (Rice, 1974). Along the California coast Baird's beaked whales apparently spend the winter and spring months far offshore and during summer move onto the continental slope where peak numbers occur during the months of September and October (Balcomb, 1989).

Mass strandings (two or more animals) of Baird's beaked whales are rare; prior to this report only two records were known. The first mass stranding reported was in the southwest Gulf of California, at El Mogote Beach in the Bay of La Paz on 2 July 1986, where seven animals were stranded (three females and four males). The body length of these animals was between 9.03 and $11.35 \mathrm{~m}$ (AuriolesGamboa, 1992). The second mass stranding was at Moroiso Point, Sagami Bay, Japan on 24 July 1987 where four animals were recorded: a $10.8 \mathrm{~m}$ lactating female, a $8.5 \mathrm{~m}$ male, a $8.2 \mathrm{~m}$ female and one whale of unknown size and sex (R.L. Brownell, unpublished data). Here we report the third mass stranding of this species, and summarize known sighting and stranding records of Baird's beaked whales in the Gulf of California.

\section{Material and Methods}

Body length was measured as the distance of a parallel line from the tip of the snout to the middle point of the flukes (Norris, 1961). The sex was evident because in

\footnotetext{
1 Departamento de Biología Marina, Universidad Autónoma de Baja California Sur. Km. 5.5 Carretera al Sur. La Paz, B. C. S. Mexico 23080.

2 NMFS Southwest Fisheries Science Center, 8604 La Jolla Shores Drive, La Jolla, CA 92037 USA.

" Corresponding autor, e-mail: jurban@uabcs.mx.
} 
all of them the penis was extruded and visible. Skin samples of each individual were collected for future studies. We collected all the teeth available, although some were missing or had been removed by fishermen. Each tooth was labeled, cleaned of tissue and dried. Two measurements were taken from each tooth: the height from the base to the apex, and the length of the base. In order to determined the age of the animals, one tooth from each animal was sagitally sectioned with a fretsaw following the methodology described by Aurioles-Gamboa (1992). A cut face from each tooth was polished with a series of three wet sand papers, from coarse to fine grain, until the surface was smooth with $1 \mathrm{~mm}$ width approximately. The teeth were then immersed in a $10 \%$ solution of formic acid for $12 \mathrm{~h}$. The counts of the group layers were in the cementum according with Kasuya (1977), directly through a stereoscope, and with edited digital photographs taken with a Nikon reflex camera of 6.0 megapixels and edited with ACDsee Pro Photo Manager program. The counts of the group layers were done by five independent individuals, three of them with experience aging this and other odontocete species. There were no important differences among the five readings. The results are the average of the five readings (Del Toro-Orozco et al., 2007).
We also compiled all known published and unpublished stranding and sighting records of this species in the Gulf of California.

\section{Results}

On 31 July 2006 a stranding of 10 whales in Bahia Amortajada (Figure 1), on the southwest coast of Isla San Jose, was reported by authorities of the Islands of the Gulf of California Conservation Program of the Mexican Federal Government. We arrived at the stranding site on August $1^{\text {st }}$ and based on fishermen interviews the stranding took place sometime during the night of 29 July 2006. The area where the whales stranded is a narrow beach of small stones (Figure 2). Nine animals were distributed along a $2100 \mathrm{~m}$ length of beach, and one was found $13.8 \mathrm{~km}$ west of the stranding site, in the Peninsula coast, presumable carried out by the currents. Based on Geraci and Lounsbury (2005), the carcasses of all whales were considered code 3: decomposed, but organs basically intact; bloating evident (tongue and penis protruding) and skin cracked and sloughing. Stomachs of two individuals (specimens 3 and 6) were examined, but there were no prey remains in either stomach.

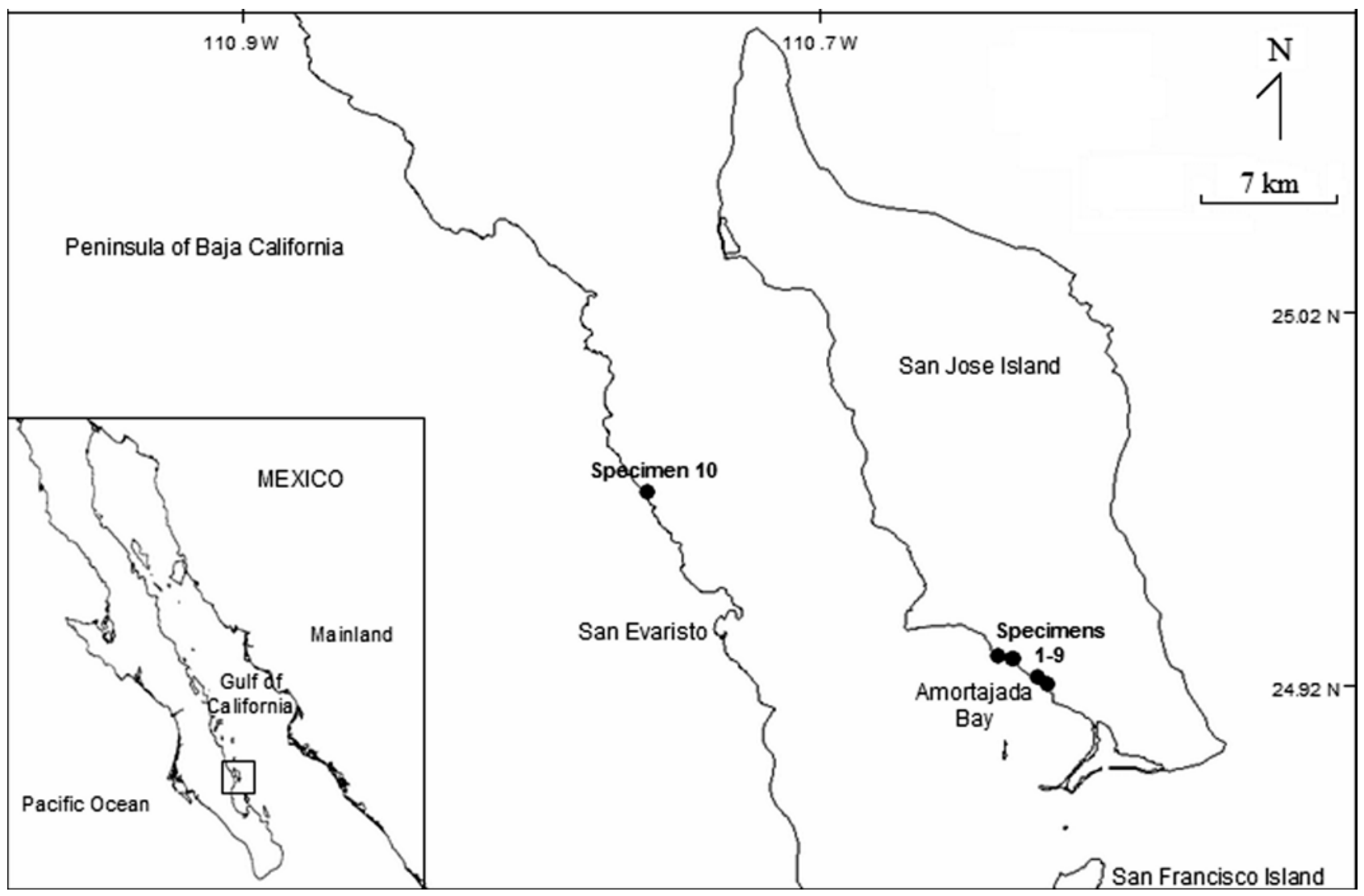

Figure 1. Stranding site of the Baird's beaked whales in San Jose Island, Mexico. 


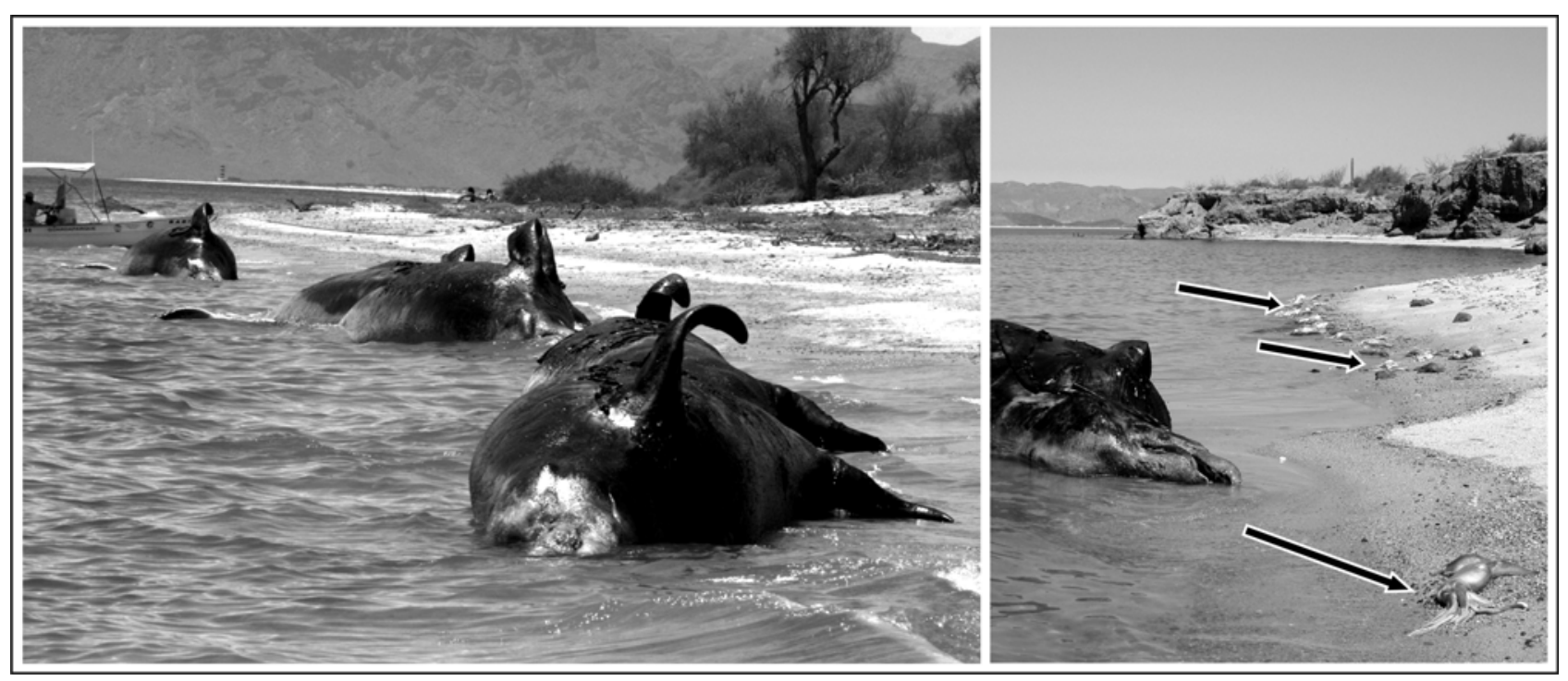

Figure 2. Left: Baird's beaked whales stranded at Bahia Amortajada. Right: Jumbo squid, Dosidiscus gigas, stranded on the beach (see arrows), at the same site where the Baird's beaked whales were found. (Photo: G. Cárdenas-Hinojosa/W. Toro-Orosco/PRIMMA).

The group was composed only by males ranging from $9.97 \mathrm{~m}$ to $11.05 \mathrm{~m}$. The estimated age, based on the dental group layers range from 9 to 42 years (Figure 3, Table 1). Hundreds of dead and dying jumbo squid (Dosidiscus gigas) were found at the beach where the whale strandings took place (Figure 2). The mantle size of some individuals were measured and ranged from 30 to $75 \mathrm{~cm}$. The whale carcasses were too decomposed for collection of tissues for histopathology, thus the cause of the stranding is unknown.

Other records of Baird's beaked whales in the Gulf of California includes four sightings (with group sizes range from 4 to 7 individuals), two single strandings (one female and one male), and one skull found on a beach (Table 2). All these records were in summer except one sighting in October. The two single strandings happened a few days after a group of Baird's beaked whales were sighted in nearby waters (Table 2).

\section{Discussion}

The cause of this stranding is unknown, although with the large number of squid also found dead in the area, it is possible that the whales could have been following the squid, one of their main prey items (Balcomb, 1989; Kasuya, 2002). This mass stranding is similar in time of the year and place to the one reported in 1986 by Aurioles-Gamboa (1992). Both happened in July and the distance between the stranding sites was only $83 \mathrm{Km}$. The particularity of the 2006 event is the group composition: all whales were males and based on the body size and estimated age all were sexual and physically mature. According to Kasuya et al. (1997) sexual maturity in males corresponds to an age of 6-11 years when the testes are histologically mature; and physical maturity, determined from the fusion of vertebral epiphyses to the centrum, is attained before 15 years of age and within five years of sexual maturity, at a mean body length of $10.10 \mathrm{~m}$ in males.

Baird's beaked whales are very gregarious, usually traveling in schools of three or more whales, but sometimes they are solitary (Balcomb, 1989); schools of 2-9 individuals constitute $64 \%$ of the encounters and singletons 14\% (Kasuya et al., 1997). Little is known about their social organization. In this species it is possible that there is sexual segregation, but if so this is not analogous to that the sperm whale; both sexes and all ages are taken in fisheries throughout the season, though females are caught in smaller proportion (Balcomb, 1989).

Thirteen of 15 Baird's beaked whales taken off California were males (Rice, 1974). Likewise, off British Columbia, 26 of 29 of those killed were males (Pike and MacAskie, 1969), and in most areas of Japan males predominate in the catch (Omura et al.,1956). This preponderance of males in the catches in certain areas suggests a partial geographical segregation of the sexes (Rice, 1974). Kasuya et al. (1997) argued against the geographical segregation base in past whaling operations in various regions of Japan and proposed, as possible explanation of this male bias, the possibility of higher natural mortality and shorter longevity for females.

Kasuya and Brownell (1989) considered that the life history characteristics of Baird's beaked whales (i.e. absence of sexual dimorphism, lower male mortality and excess of mature males over females) were quite different from those known among polygynus mammals, and speculated that the species may have developed a reproductive system in which the contribution of old males in rearing weaned calves might be significant. 

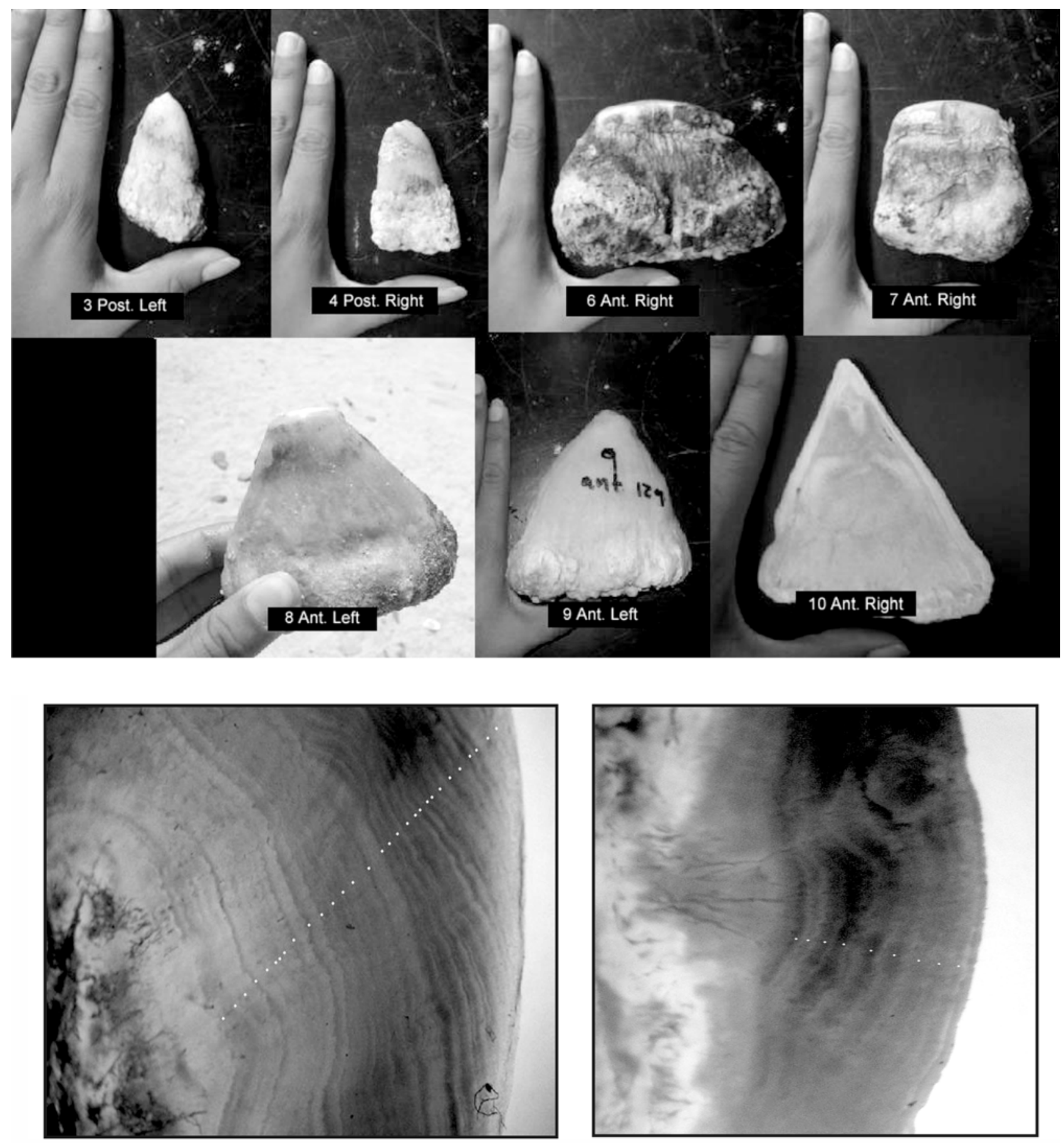

Figure 3. a) Teeth used in the age determination of seven individuals. b) View of the group layers of individual \#6. c) View of the group layers of individual \#10. White dots indicate each group layer. (Photo: W. Toro-Orozco).

Our knowledge of the school composition of Baird's beaked whales is limited, based only on two previous mass strandings and the one presented here. In the mass stranding at the Bahia de La Paz in 1986 (Aurioles-Gamboa, 1992), the presence of two mature females (13 and 17 years old) and four mature males (20-42 years old), suggest that Baird's beaked whales live, at least some of the time, in mixed schools of mature males and females. The mass stranding from Japan in 1987 (R.L. Brownell, unpublished data), consisting of a lactating female $(10.8 \mathrm{~m})$, one immature male $(8.5 \mathrm{~m})$, one immature female $(8.2 \mathrm{~m})$ and one of unknown sex and size, is similar to a female social unit in sperm whales, which consists of mature females and calves and juveniles males and females (Rice, 1989; Whitehead, 2002). The mass stranding 
presented here of 10 mature males of different ages (8-40 years old) suggest a sex segregation supporting the reproductive strategy proposed by Kasuya and Brownell (1989) $)^{3}$.

To conclude, the mass stranding of 10 mature males reported here, support the idea of a seasonal presence, during summer, of this species in the waters of the southwest Gulf of California. The group composition supports a reproductive strategy where the old males have a major role in the guidance and protection of inexperienced weaned and young males, unlike sperm whale bachelor groups, where all males are typically the same age. The presence of records of mature males and females in the area in the same season refutes the hypothesis of geographic and/or seasonal segregation of males and females.

Table 1. Body length of the stranded specimens and information on teeth.

\begin{tabular}{rcccc}
\hline \hline SPECIMEN & $\begin{array}{c}\text { BODY LENGTH } \\
(\mathrm{m})\end{array}$ & $\begin{array}{c}\text { TEETH } \\
\text { COLLECTED }\end{array}$ & $\begin{array}{c}\text { TOOTH } \\
\text { GROWTH LAYERS }\end{array}$ & $\begin{array}{c}\text { TOOTH } \\
\text { SIZE }(\mathrm{mm})\end{array}$ \\
\hline \hline 1 & 10.62 & - & - & - \\
2 & 10.60 & - & - & - \\
3 & 10.03 & PL & 17.25 & $310 \mathrm{~W}, 560 \mathrm{H}$ \\
4 & 10.30 & PR & 42.50 & $320 \mathrm{~W}, 590 \mathrm{H}$ \\
5 & 10.10 & - & - & - \\
6 & 10.19 & AR & 30.25 & $980 \mathrm{~W}, 703 \mathrm{H}$ \\
7 & 10.83 & AR & 17.5 & $588 \mathrm{~W}, 658 \mathrm{H}$ \\
& & AL & - & $632 \mathrm{~W}, 660 \mathrm{H}$ \\
& & PR & - & $360 \mathrm{~W}, 550 \mathrm{H}$ \\
& & PL & - & $349 \mathrm{~W}, 551 \mathrm{H}$ \\
8 & 9.97 & AL & 31.25 & $805 \mathrm{~W}, 755 \mathrm{H}$ \\
& & PR & - & $365 \mathrm{~W}, 535 \mathrm{H}$ \\
& & PL & - & $340 \mathrm{~W}, 520 \mathrm{H}$ \\
9 & 10.60 & AR & 15.5 & $1030 \mathrm{~W}, 892 \mathrm{H}$ \\
10 & 11.05 & AR & 9.0 & $810 \mathrm{~W}, 845 \mathrm{H}$ \\
& & AL & - & $845 \mathrm{~W}, 910 \mathrm{H}$ \\
\hline \hline
\end{tabular}

[AL: anterior left, AR: anterior right, PL: posterior left, PR: posterior right. W: width, H: high. Tooth size in millimeters.]

Table 2. Previous records of Baird's beaked whales in the Gulf of California.

\begin{tabular}{|c|c|c|c|c|c|c|c|}
\hline RECORD & DATE & Place & COORDINATES & No. & $\begin{array}{c}\text { BODY } \\
\text { LENGTH }(\mathrm{m})\end{array}$ & AGE/SEX & SOURCE \\
\hline Sighting & 16 June 1987 & Gulf of California & $23^{\circ} 15^{\prime} \mathrm{N} ; 109^{\circ} 21^{\prime} \mathrm{W}$ & 4 & & Unknown & A \\
\hline Sighting & 13 October 1987 & Gulf of California & $24^{\circ} 34^{\prime} \mathrm{N} ; 109^{\circ} 59^{\prime} \mathrm{W}$ & 5 & & Unknown & A \\
\hline Sighting & 05 June 1990 & $\begin{array}{l}\text { Canal de San } \\
\text { Lorenzo }\end{array}$ & $24^{\circ} 22^{\prime} \mathrm{N} ; 110^{\circ} 17^{\prime} \mathrm{W}$ & 6 & & Unknown & B \\
\hline Sighting & 01 July 2007 & Bahia de La Paz & $24^{\circ} 20^{\prime} \mathrm{N} ; 110^{\circ} 27^{\prime} \mathrm{W}$ & 7 & $\begin{array}{c}10-10.5 \\
\text { estimate }\end{array}$ & Unknown & $\mathrm{C}$ \\
\hline Skull collected & 13 August 1964 & Isla San Esteban & $28^{\circ} 40^{\prime} \mathrm{N} ; 112^{\circ} 14^{\prime} \mathrm{W}$ & 1 & & Unknown & $\mathrm{D}, \mathrm{E}$ \\
\hline Single stranding & 09 June 1990 & El Mogote & $24^{\circ} 12^{\prime} \mathrm{N} ; 110^{\circ} 19^{\prime} \mathrm{W}$ & 1 & 10.5 & Mature/f & B \\
\hline Single stranding & 12 July 2007 & El Mogote & $24^{\circ} 10^{\prime} \mathrm{N} ; 110^{\circ} 26^{\prime} \mathrm{W}$ & 1 & 10.75 & Mature/f & C \\
\hline Mass stranding & 02 July-1986 & El Mogote & $24^{\circ} 10^{\prime} \mathrm{N} ; 110^{\circ} 22^{\prime} \mathrm{W}$ & 7 & $9.05-11.35$ & $\begin{array}{c}2 \text { Inmature } / \mathrm{f} \\
1 \text { Mature } / \mathrm{f} \\
3 \text { Mature } / \mathrm{m}\end{array}$ & $\mathrm{F}$ \\
\hline
\end{tabular}

Size in meters. [A: Aguayo et al. (1988); B: Urbán and Jaramillo (1992); C: J. Urbán R. Unpub. data; D: Mead et al. (1998); E: Vidal (1991); F: Aurioles-Gamboa (1992)]

\footnotetext{
${ }^{3}$ Kasuya, T. and Brownell, R.L., Jr. (1989) Male parental investment, an interpretation of the age data. Page 523 in Abstracts, 5 th Theriological Conference, 22-29 August, Rome, Italy.
} 


\section{Acknowledgments}

The authors thank their colleagues from the Marine Mammal Laboratory, UABCS, Sylviane Jaume, Mercedes Guerrero, Christian Salvadeo, Sergio González and Benjamín Troyo for their help in the field work. Victor Flores of CONANP gave us the notice of the stranding. David Aurioles advised us the technique to read the dentine bands in the teeth. We also are very grateful to Robin Baird and an anonymous reviewer for their many careful and constructive comments and suggestions on our draft paper. This study was conducted with the financial support of the CONACYT and the University of California, San Diego, and under research permit from SEMARNAT.

\section{References}

Aguayo L., A., Aurioles G., D., Urbán R., J., Salinas Z., M., Vidal, O. And Findley, L.T. (1988) Beaked whales in Mexican waters. Paper SC/40/SM23 presented to the International Whaling Commission Scientific Committee, May 1988. San Diego, CA, USA. 6 pp.

Aurioles-Gamboa, D. (1992) Notes on a mass stranding of Baird's beaked whales in the Gulf of California, Mexico. California Fish and Game 78:116-123.

BALCOMB, III, K.C. (1989). Baird's beaked whale Berardius bairdii Stejneger, 1883; Arnoux's beaked whale Berardius arnuxii Durvenoy, 1851. Pages 261-288 in Ridgway, S.H. AND HARRISON, R. (Eds) Handbook of Marine Mammals. Volume 4: River Dolphins and the Larger Toothed Whales. Academic Press. London, United Kingdom.

Del Toro-Orozco, W., Cárdenas-Hinojosa, G., GómezGallardo U., A., González-Peral, U. and Urbán R., J. (2007) Determinación de edad por medio de bandas de crecimiento en dientes de individuos varados de Berardius bairdii (Cetacea: Ziphiidae). Revista Biológicas 9: 25-30.

GeRACI, J.R. AND Lounsbury, V.J. (2005) Marine Mammals Ashore: a Field Guide for Strandings. Second edition. National Aquarium in Baltimore, Baltimore, MD, USA. 371 pp.

KASUYA, T. (1977) Age determination and growth of the Baird's beaked whale with comment on the fetal growth rate. The Scientific Reports of the Whales Research Institute 29:1-20.

KAsuYA, T. (2002) Giant beaked whales Berardius bairdii and B. arnuxii. Pages 519-522 in Perrin, W.F., WÜRSIG, B. AND THEWISSEN,
J.G.M. (Eds). Encyclopedia of Marine Mammals. Academic Press. San Diego, CA, USA.

Kasuya, T., Brownell, R.L., JR. And BALcomb III, K.C. (1997) Life history of Baird's beaked whales off the Pacific coast of Japan. Report of the International Whaling Commission 47: 969-979.

Mead, J.G., Heyning, J.E. And Brownell, R.L., JR. (1988) Distribution and exploitation of beaked whales in the Northern Hemisphere. Paper SC/40/SM21 presented to the International Whaling Commission Scientific Committee, May 1988. San Diego, CA, USA. 11 pp.

Leatherwood, S., Reeves, R.R., Perrin, W.F. and Evans, W.E. (1988) Whales, Dolphins and Porpoises of the Eastern North Pacific and Adjacent Arctic Waters: A Guide to their Identification. Dover Publications. New York, NY, USA. 245 pp.

NoRRIS, K.S. (1961) Standardized methods for measuring and recording data on the smaller cetaceans. Journal of Mammalogy 42(2): 471-476.

Omura, H., Fujino, K. And Kimura, S. (1956) Beaked whales Berardius bairdii of Japan. The Scientific Reports of the Whales Research Institute. 10: 89-132.

Pike, G.C. And MacAskie, I.B. (1969) Marine mammals of British Columbia. Journal of the Fisheries Research Board of Canada. 171: $1-54$.

Rice, D.W. (1974) Whales and whale research in the eastern North Pacific. Pages 170-195 in SchevilLe, W.E. (Ed) The Whale Problem. A Status Report. Harvard Univ. Press. Cambridge, MA, USA.

Rice, D.W. (1989) Sperm whale Physeter macrocephalus Linneaus, 1758. Pages 261-288 in RIDGWAY, S.H. AND HARRISON, R. (Eds). Handbook of Marine Mammals. Volume 4: River dolphins and the larger toothed whales. Academic Press. London, United Kingdom.

Urbán R., J. AND Jaramillo, L.A. (1992) Segundo varamiento de Berardius bairdii en la Bahia de La Paz, B.C.S. Revista de Investigación Científica 3(1): 85-92.

VIDAL, O. (1991) Catalog of osteological collections of aquatic mammals from Mexico. NOAA Technical Report NMFS 97: 136. Springfield, VA, USA.

Vidal, O., Findley, L.T. And Leatherwood, S. (1993) Annotated checklist of the marine mammals of the Gulf of California. Proceedings of the San Diego Society of Natural History 28: 1-16.

Whitehead, H. (2002) Sperm whale Physeter macrocephalus. Pages 1165-1172 in PerRin, W.F., WÜrsig, B. AND THEWISSEN, J.G.M. (Eds) Encyclopedia of Marine Mammals. Academic Press. San Diego, CA, USA 